\title{
GOOD GOVERNANCE IN THE PERSPECTIVE OF MALAY CUSTOMS AND THE QUR'AN
}

\author{
Muhammad Ilham \\ STAI Ahsanta Jambi, Indonesia \\ E-mail: Ilham7964@gmail.com \\ Mastikawati \\ STAI Ahsanta Jambi, Indonesia \\ E-mail: mastikaika333@gmail.com
}

\begin{abstract}
This article focused on good governance in the perspective of Malay customs and the Koran. This article aimed to understand; the concept of good governance according to Malay customs and the Qur'an. Utilizing library sources (Library Research) to obtain data from reading materials that are accurate and relevant to the research discussion, and identify the data according to the steps, then proceed with analyzing the data using the Tafsir al-Adabiy al-Ijtima'i (sociocultural) Thematic Tafsir methodology. This study concluded that good governance according to Malay customs contains the principles of good governance according to cos and the construction of good governance is manifested in seloko, and good governance does not conflict with the spirit of the Qur'an and al-Hadith. The principle of good governance in Jambi Malay customs is identical to the principle of governance in the Qur'an.
\end{abstract}

Keywords: Good Governance, Malay Custom, Al-Qur'an.

\section{INTRODUCTION}

Good Governance is a new approach offered by international institutions. This activity fulfills four aspects. ${ }^{1}$ First, the principle of social justice, in which an independent court system is obtained. Second, equitable distribution of development results while at the same time providing freedom in the economy. Third, the diversity of political dynamics is characterized by the principle of equity

1 Syarkani, Re-Spiritualizing Governance (Yogyakarta: Pustaka Pelajar, 2010). 
IJIERM: Vol. 3 No. 1 January - March 2021

and community participation. Lastly, government accountability. ${ }^{2}$ Bureaucratic reform as a manifestation of good governance touches its supporting pillars and its substance covers the fields of organization, management, and human resources that have a foundation and direction. ${ }^{3}$

Indigenous peoples of Jambi Malay almost all of the rules have been regulated by the custom itself as outlined in the traditional expression of Jambi Malay customs (seloko customs), as in an effort to build a performance management system and the formation of good governance. Good governance is associated with the Jambi Malay traditional community, because some Jambi people adhere to customs and culture enriched with various Islamic treasures wrapped in it. Customs is part of culture, used as a way of life for the state and society before and after Islam came, so custom has become the pillar of the Jambi community, which is based on the customary tradition of "Induk undang tambang teliti, titian teras bertanggo batu, kaco gedang nan idak kabur, tonggak nan idak dapat digoyangkan, baju bejait nan dipakai, jalan berambah nan ditempuh". It means that the customary rules that are carried out and implemented are the result of democratization along with the principle of consensus, and consensus must also be sourced from the normative truth (the Mother Law), namely the Qur'an. ${ }^{4}$

The Qur'an coincides with the journey of Jambi Malay customs and is open to local interpretation, guidance and development, as long as local culture is in line with the Qur'an, this is contained in the customary law of "Adat bersendi Syara'; Syara' bersendi Kitabullah; Syara' mengato Adat memakai". ${ }^{5}$ On this basis, traditional stakeholders assume that customs must not conflict with the principles of the Qur'an and must be adjusted as long as the culture of the community is out of shari'ah pathways.

Messages, seloko which are full of advice and direction towards the formation of good governance and ideal society in Jambi Province which are sourced from the Qur'an. In addition, the values that are born from the customs, culture and local wisdom of the Jambi community are filtered by the rules

2 Sedarmayanti, Good Governance; Kepemerintahan Yang Baik (Bandung: Penerbit Mandar Maju, 2004).

3 Agus Dwiyanto, Reformasi Birokrasi Publik Di Indonesia (Yogyakarta: Gadjah Mada University Press, 2006).

4 Thabran Kahar, Ungkapan Tradisional Sebagai Sumber Informasi Kebudayaan Daerah Jambi (Jambi: Departemen Pendidikan dan Kebudayaan, 1987).

${ }^{5}$ A. Wahab Madjid, Garis-Garis Besar Pedoman Adat Bagi Pemangku Adat Dalam Kotamadya Dati II Jambi (Jambi: lembaga Adat Tingkat II dan PemerintahanKotamadya Dati II Jambi, 1995). 
IJIERM: Vol. 3 No. 1 January - March 2021

formulated in the seloko circle "Adat bersendi Syara', Syara' bersendi Kitabullah". In other words, the ideas of good government and good governance are not foreign to the Jambi Malay indigenous people and even Muslims in general. This study attempts to explain how good governance is in the traditional Malay seloko-seloko Jambi from the perspective of the Qur'an.

\section{GOOD GOVERNANCE IN JAMBI MALAY TRADITIONAL SELOKO FROM} AL-QUR'AN PERSPECTIVE

Good governance is expanded into five important elements, namely: Transparency, consistency, intelligence, accountability and comunicatibility. First, Transparency means that every individual or one element of the government system acts openly in carrying out their duties. Every activity can always be proven with strong, valid, reliable and accurate data. Second, consistency is more about mental attitude and personality. Every actor in state institutions should be firm in their stance, not denying it and even trying to make it happen, even though they are faced with personal difficulties, bureaucrats like this are not easily changed and swayed by the temptations around them. Third, intelligence is a person's personal ability because it is related to intelligence. This intelligence is expected to help smooth the daily tasks of a bureaucrat in an institution, because it can predict positive and negative things that will happen. Fourth, accountability means a sense of responsibility by maintaining a work attitude what is mandated is always done with maximum responsibility, not random. And the last is communicability or the ability to communicate well, respectfully, respectfully and politely. If these five concepts are applied in government, according to adherents of this theory, the government of a country will be good, clean, healthy, authoritative, and responsible. ${ }^{6}$

1) Principles of Good Governance. The following are various principles in government practice that adhere to the good governance project:

a. Participation, that is, every community has the same rights in making decisions, directly and in a representative system, based on their respective interests and aspirations.

${ }^{6}$ From Governance to Governance, the Growing Impact of Non-State Actors on the International Dan European Legal System, ed. by Wybo P. Here (Netherlands: TMC ASSER PRESS, 2003). 
IJIERM: Vol. 3 No. 1 January - March 2021

b. Rule of Law, legal products take place fairly, are carried out with full obedience in a holistic manner, indiscriminately, and uphold Human Rights (HAM).

c. Transparency, transparency is implemented on the basis of freedom of information.

d. Responsiveness, governance is directed at the service of parties who have an interest.

e. Consensus orientation, good governance is an intermediary between parties with different interests to obtain consensus (choice) and allow it to be determined as a government regulation.

f. Equity, the government provides guarantees and rights for every individual in improving the quality of life towards a more prosperous.

g. Effectiveness and efficiency, activities and institutions are formed based on the needs and the best possible use of resources that are owned efficiently and effectively.

h. Accountability, the determined policy is responsible for the public and the parties concerned.

i. Strategic Vision, governance is carried out in order to meet the needs of human development. ${ }^{7}$

This principle is closely related to human rights, this is because good governance serves to fulfill the public interest. ${ }^{8}$ The various principles above are very relevant to the governance that is aspired to, both by modern society, as well as by indigenous peoples.

2) Good Governance from the perspective of Malay customs and the Qur'an

Adat bersendi syara', syara' bersendi Kitabullah as a cover, and at the same time a cultural symbol to see people's behavior in understanding the relationship between customs and the religion they embrace. ${ }^{9}$ The relationship is not reciprocal on the same level (collateral), but hierarchicalvertical, religion marked with syara' occupies a higher position than customs, and religion is referred to the word of Allah (al-Qur'an), the revelation given to the Prophet Muhammad SAW. As a guide and guide. Customs related to

7 Sedarmayanti, Good Governance; Kepemerintahan ..., p. 5-6

8 Oheo K. Haris, 'Good Governance (Tata Kelola Pemerintahan Yang Baik) Dalam Pemberian Izin Oleh Pemerintah Daerah Di Bidang Pertambangan', Yurdika, 30.1 (2015), p. 58-82.

9 Sagimun M.D, Adat Istiadat Daerah Jambi (Jakarta: Departemen Pendidikan dan Kebudayaan, 1978). 
IJIERM: Vol. 3 No. 1 January - March 2021

religion or syara' are those that do not oppose religion, while those that are contrary are discarded. Customs that do not violate religion are called Islamic customs (Islamiyah customs). In its implementation, phrases such as the one at the beginning of this paragraph appear. ${ }^{10}$

The Jambi Malay community is predominantly Muslim, which has implications for customary rules or laws that are colored by Islamic teachings. This belief resulted in the agreement of Muslims in the Jambi sultanate to stick to the agreement that was formulated in the adage "Syara', Syara' based on Kitabullah" not the other way around. Religions before and after that attempted to influence Islam were emphatically rejected. ${ }^{11}$

So it is only natural that the customary rules or laws owned by the Jambi Malay customs contain the message of Islam implicitly. The Jambi Malay Customary Seloko said " Adat selingkung koto, undang selingkung alam, adat di tangan nenek mamak, undang di tangan rajo, rumah bertengganai, kampung betuo, luhak berpenghulu, rantau bejenang, negri bebatin, alam berajo ", the lives of the Jambi Malay people are in a The Koto Selingkung custom and the Nature Selingkung Law. The Jambi Malay community enforces a higher level of law than customary law. The message is implied in this seloko, that all problems are resolved by custom before punishing the Law on Selingkung Alam. The point here is that throughout human history it is known that the so-called human has the desire to walk to a place or better known as wandering. This desire is due to the urge to seek knowledge. It could also be because they are motivated to try to find sustenance in overseas areas while in their own place it feels very cramped and difficult to earn a living. The nomad is reminded that every place has rules. So that he realized himself, so as not to commit violations in the new place he visited. He is required to be good at carrying himself. If he gets into any trouble then tell the local authorities to end it. ${ }^{12}$

Another Seloko also said, "tumbuh kareno ditanam, tinggi kareno dianjung, gedang kareno dilambuk, muliyo kareno dihormati, bukan cucur dari langit idak tumbuh dari bumi. Seorang pemimpin itu bercakap dulu sepatah, berjalan dulu selangkah, makan ngabis nyicang mutus. Karena itu seorang pemimpin harus berwatak, kalu berpikir tidak sekali sudah, berunding tak sekali putus, cukup dengan 2001).

${ }^{10}$ Lembaga Adat Provinsi Jambi, Pokok-Pokok Adat Pucuk Jambi Sembilan Lurah,Jilid II (Jambi,

11 Ibid.

12 Thabran Kahar, Ungkapan Tradisional Sebagai..., p.25 
IJIERM: Vol. 3 No. 1 January - March 2021

sisik dan siangnyo. Sebab seorang pemimpin seperti, kayu gedang di tengah padang, daun rindang tempat berteduh, dahannyo tempat bergantung, batangnyo gedang tempat bersandar, akarnyo kukuh tempat bersilo, kok pergi tempat bertanyo, kok balik tempat berito. ${ }^{13}$ It means: who becomes a leader is the chosen one, must be supported and respected. A leader is the prime mover, should not jump to conclusions in haste because he is endowed with reason that will guide him strictly. ${ }^{14}$ Therefore, the leader must have character, so that he can serve his people well. This is a requirement as a leader that must be carried out.

As a leader, he must enforce the rule of law, such as seloko; menurut runut nan terentang sejak bari, menempuh jalan nan berambah sejak dulu, is a message to us to get used to being guided by the existing ones. Equity is like seloko; It's like breaking a botung when it's stepped on by a gi being lifted up high, meaning that because there are still many people who are unfair, we are ordered to always do justice in all our actions. This slightly represents the Jambi Malay traditional relationship and good governance and there are many more principles of good governance such as Participation, Transparency, Responsiveness, Consensus orientation, Effectiveness and efficiency, Accountability, and Strategic Vision. In the principles of good governance according to Jambi Malay customs, it is also contained in selokoseloko which becomes the guidance and customary provisions for religious guidance.

The principles of good governance in Jambi Malay customs are fused in the seloko which is a legacy from time to time. The following can be seen more specifically these principles:

\section{a. Participation}

Every individual is treated and given the same rights in making decisions. ${ }^{15}$ This principle is in accordance with the Jambi Malay traditional chorus which reads: Mudik serentak satang ilir serengkuh dayung. The point is that heavy and light work should be completed or done together, because social life contains provisions that include all members of the community. These provisions and obligations have accustomed people to always work together in doing something, for example building and cleaning villages; build a mosque and langgar as a place of worship;

${ }^{13}$ A. Wahab Madjid, Garis-Garis Besar Pedoman Adat..., p.42

14 Thabran Kahar Thabran Kahar, Ungkapan Tradisional Sebagai..., p.50

${ }^{15}$ Sedarmayanti, Good Governance; Kepemerintahan ..., p.15 
IJIERM: Vol. 3 No. 1 January - March 2021

establish a madrasa where education; cleaning pandam graves; make the edge of the bath; help the mind, the prince, and Syara' employees to make fields or fields; helping the poor and the weak; as well as helping villagers who were struck by disaster. Likes to work together not only in small and easy things, but also working together for big and difficult things.

Everything is done voluntarily and sincerely. If any of the villagers who are going home don't want to go up and down at the same time and don't want to srengkung paddle, meaning that they want to reign in their hearts, they will surely be abandoned by the people of their village and will be excluded from all activities and negotiations. Such people are not infrequently forced to leave their hometowns to go overseas, bringing with them the qualities that are not commendable. ${ }^{16}$

In line with the Word of Allah SWT which explains this, then there should be no envy when each of us participates in various aspects of life to realize the value of good governance, moreover Allah SWT sees and evaluates every participation we participate in. This is in the Word of Allah SWT in QS. An-Nisa' verse 32, QS. At-Taubah verse 105 and QS. Al-Hujurat verse 13:

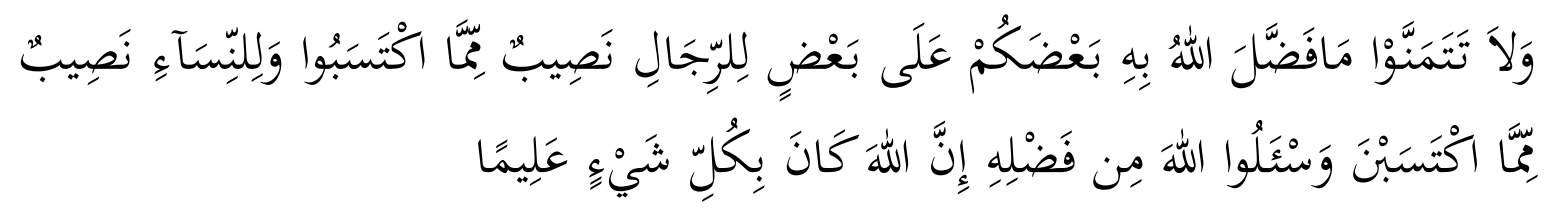

Meaning: "And do not be jealous of what Allah has bestowed on some of you more than some of you. (Because) for men there is a share of what they earn, and for women (also) there is a share of what they earn, and ask Allah for a portion of His bounty. Verily Allah is Knower of all things."17

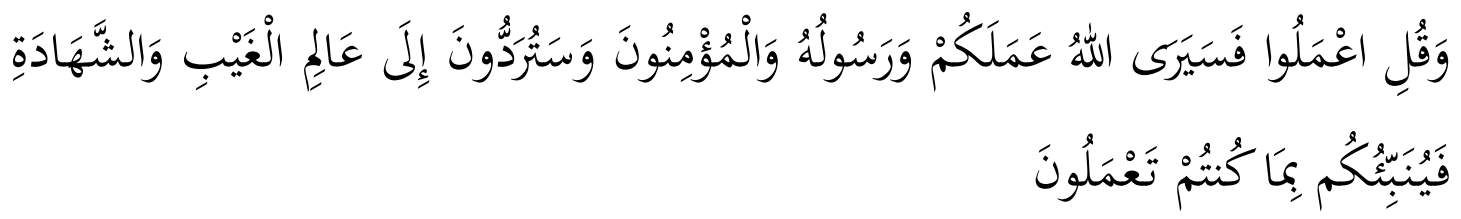

16 Thabran Kahar Thabran Kahar, Ungkapan Tradisional Sebagai..., p.70

${ }^{17}$ Q.S. An-Nisa/4:32. 
IJIERM: Vol. 3 No. 1 January - March 2021

Meaning: "And say: "Work you, then Allah and His Messenger and the believers will see your work, and you will be returned to (Allah) Who knows the unseen and the real, then He will give it to you. you what are you doing". ${ }^{18}$

\section{b. Rule of law}

This principle is also stated in the Jambi Malay traditional verse which reads: Menurut runut terentang sejak bari, menempuh jalan nan berambah sejak dulu.. The point is to follow the guidelines that already exist, because customs regarding laws, regulations, laws and customs, and associations in general have been wisely outlined by our predecessors. All these noble habits until now are considered good and can be used in living systems. Runut means the marks left by pedestrians, which can be followed from the beginning. If someone is going to follow the journey on foot, he must follow the trail from the beginning. This means that someone was not allowed to follow the trail starting from the middle, the possibility of the pedestrians being followed had deviated, turned elsewhere, before reaching the middle. So in following legal customs and legislation, stipulations, customs, and associations should not be half-measures but must be a complete whole. In addition, it should not be according to personal preferences, because it will be very contrary to the actual situation. One must take a path that is already clear because it has been cut off and people are used to it. Especially if the trip is done in the forest. When traveling in the forest as was the custom of the past, so as not to get lost, make it a habit to walk on roads that have been cleared and are used to by people. Thus the expression above advises us to get used to being guided by the existing ones. ${ }^{19}$

Another seloko regarding the rule of law is that which reads: Rumah betengganai, kampung betuo, luak bepenghulu, rantau bejenjang, negeri bebatin, alam berajo. It means that every country, region, or place has a leader and ruler. From the small, namely the household to the largest, namely the state (nature), there are leaders as rulers. The power of each of these rulers is limited by law as befits the size of an area and the status it has. Thus, it is certain that no matter how small a society is, there must be a leader who will direct and guide all their daily activities. This phrase is a piece of advice that reminds everyone that he cannot do what he wants in this world. Wherever he goes he must know that every place or country

${ }^{18}$ Q.S. At-Taubah/9:105.

19 Thabran Kahar, Ungkapan Tradisional Sebagai..., p.102 
IJIERM: Vol. 3 No. 1 January - March 2021

has a leader and has its own customs. He must be able to control himself when he is abroad and must be able to adapt to the area he occupies. He must be able to respect the leaders, customs, and customs of a place or country. ${ }^{20}$

Even this principle is in accordance with the Word of Allah SWT regarding the obligation to uphold justice indiscriminately, Allah SWT asserts in QS. AlMaidah verse 8:

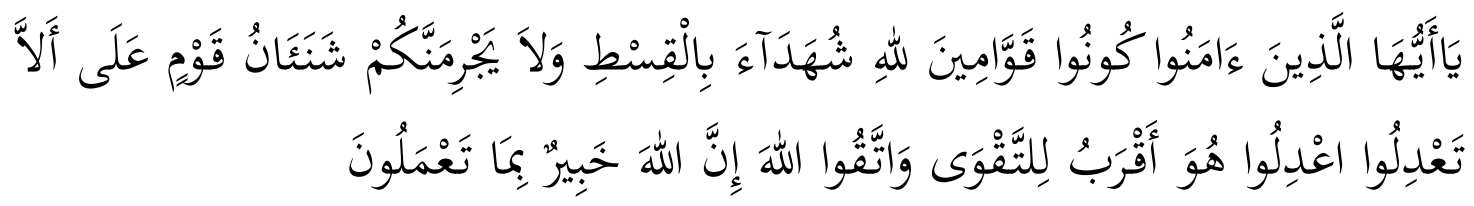

Meaning: "O you who believe, let you be those who always uphold (the truth) for the sake of Allah, as witnesses of justice. And don't let your hatred of a people encourage you to act unjustly. Be fair, because fair is closer to piety. And fear Allah, verily Allah is aware of what you do. ${ }^{21}$

\section{c. Transparency}

This is stated in the Jambi Malay traditional chorus which reads: Tebing runtuh tepian beranjak tanjung putus teluk beralih. The meaning is that every event brings change because in this mortal world nothing is eternal, everything is only temporary. Transience itself is different, sometimes long and fleeting. Edges don't always stay in place. If the cliff collapses then the bank can move its location. Likewise, the bay can switch if the headland that formed it has broken up. Every time there is an event that will bring about a change, as in the replacement of a leader, new policies will be found that must be implemented. The new leader will use the new wisdom as well. It's just that the policy that will be implemented must be in favor of the interests of the people (transparent). This is where the essence of the expression above wants to remind us that a leader has the freedom to develop his thoughts as long as his new conception can be accepted by many people and was born for the benefit of many people. ${ }^{22}$

Another seloko that reads: Tetangguk pado ular dikeruntungkan, tetangguk pado ikan dikeruntungkan. The point is that those who are benefited are carried away because the good and bad experienced by friendship must be felt together. Snakes

20 Ibid..., p.108

21 QS. Al-Maidah/5:8.

22 Thabran Kahar, Ungkapan Tradisional Sebagai..., p.200 
IJIERM: Vol. 3 No. 1 January - March 2021

and fish are two very different types of animals. In fulfilling their daily needs, ethnic Malay Jambi residents fish in rivers, lakes, or the sea. People can catch fish by nodding it. Their experience in nodding apparently occasionally is not only fish but also snakes. Even if the person caught is a snake, they also put it in the bed. Events like this they lift into expressions to express the demands of true friendship. Whatever is experienced by a friend must be felt together as a sign of a loyal friend. We don't just want to feel the good things, but if our friends experience bad things, we must also feel them together. By doing this we have experienced the joys and sorrows of our friends. ${ }^{23}$

The principle of Transparency is also in line with the word of God which curses those who hide the truth even though they know it. As emphasized in QS. Al-Baqarah verse 146 and QS. Al-Baqarah verse 283:

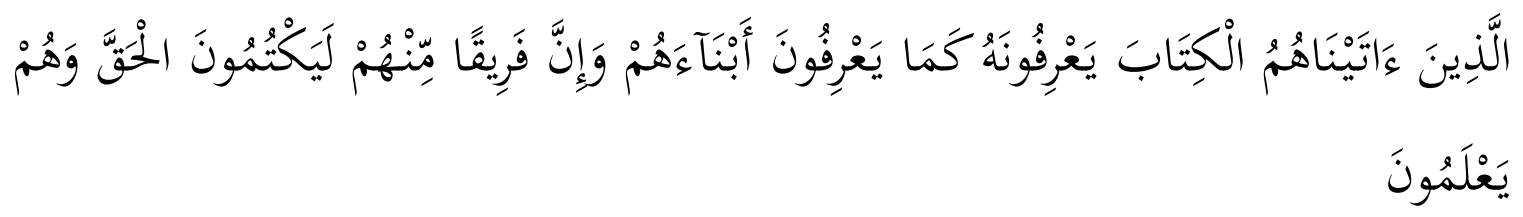

Meaning: "Those (Jews and Christians) to whom We have given the Book (Torah and Gospel) know Muhammad as they know their own children. And indeed some of them hide the truth, even though they know."24

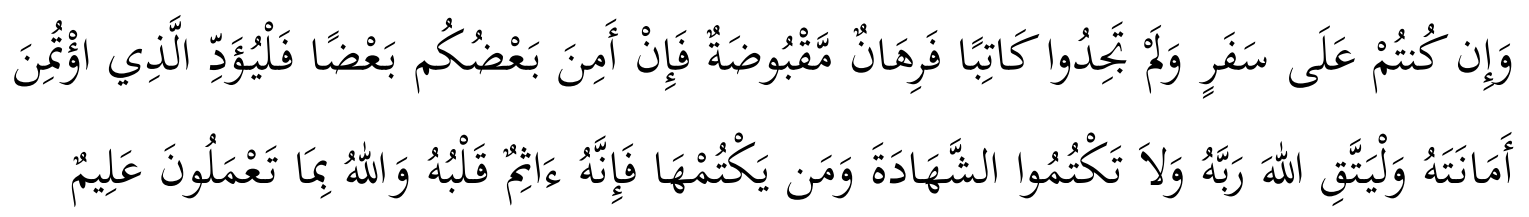

Meaning: "If you are on a journey (and do mu'amalah not in cash) while you do not find a writer, then there should be collateral held (by the debtor). But if some of you believe in others, then let the one who is trusted fulfill his mandate (his debt) and let him fear Allah, his Lord; And do not (witnesses) hide your testimony. And whoever hides it, then indeed he is a sinner in his heart; and Allah knows what you do."25

${ }^{23}$ Ibid..., p. 202

${ }^{24}$ Q.S. Al-Baqarah/2:146.

${ }^{25}$ Q.S. Al-Baqarah/2:283. 
IJIERM: Vol. 3 No. 1 January - March 2021

\section{d. Responsive}

The point is that every government administration is based on public trust in government services, both responsive to problems and in decisions. ${ }^{26}$ It is said in seloko: Macam mukut di mulut gantang. The meaning is responsive to follow-up. Lemukut is a rice head whose size is so small that it is always not taken into account and is often thrown away. Someone who is likened to a lemukut is classified as one who does not need to be invited to participate in solving a case or deed, both small and large. Such people are always excluded because according to the assessment they do not have any abilities. Even though he is included, it is certain that it will burden those who are carrying out their duties earlier. Sometimes the above expression is used by someone to deliberately humiliate themselves, for example; "Ah, I'm just like a lump in the mouth of a bushel in and out not reducing." That person is actually the party most expected to contribute his energy and thoughts by the group. However, as a courtesy he used the expression earlier. $^{27}$

Seloko on other responsiveness: Macam mengayuh perau kilirThe point is to get a job done without any effort. For example, rowing a boat upstream is different from rowing a boat downstream. Upstream is clearly against the current and requires a lot of energy. While rowing a boat downstream does not require a lot of energy because it is helped by the swift currents that are indeed heading downstream. This expression is addressed to someone who finds or gets the task of completing something that is very easy to do. In this expression there is a piece of advice so that when someone finds tasks that are easy to complete, they should not forget themselves. And don't be so arrogant that you underestimate the task at hand. ${ }^{28}$

The principle of Responsiveness is in line with the Word of Allah SWT which explains the prohibition of being stubborn, having to forgive each other, and deliberation in every decision, as the Word of God in QS. Ali-Imran verse 159:

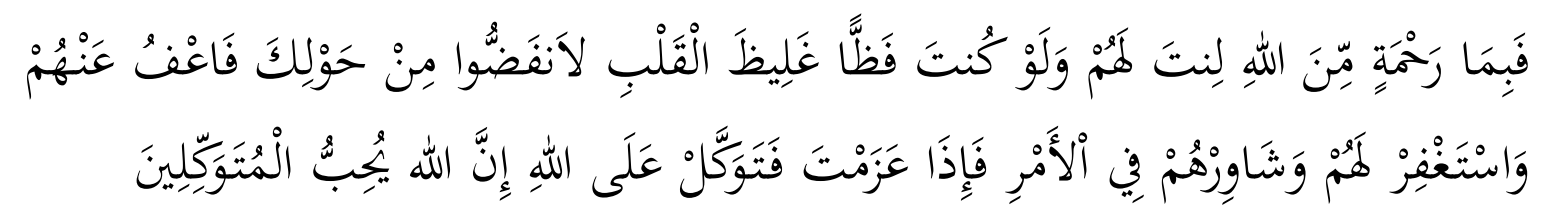

26 Sedarmayanti, Good Governance; Kepemerintahan ..., p.140.

27 Thabran Kahar, Ungkapan Tradisional Sebagai..., p.250

28 Ibid..., p. 245. 
IJIERM: Vol. 3 No. 1 January - March 2021

Meaning: "So it is because of the mercy of Allah that you are gentle with them. If you are hardhearted and harsh-hearted, they will certainly distance themselves from those around you. Therefore forgive them, ask forgiveness for them, and consult with them in this matter. Then when you have made up your mind, then put your trust in Allah. Verily, Allah loves those who put their trust in Him."29

\section{e. Consensus Oriented}

The Jambi Malay traditional Seloko states: Dilasak layu diguyur mati.. The point is a decision that cannot be changed anymore, if forced to change it will have bad consequences. This can be likened to a plant that has grown if forced to remove it will wither, or if forced to move it will die. In everyday life there are often disputes between parties who have made peace because there are parties who want to change decisions or agreements that have been made. Indeed, in making a decision, one must be firm so that there is no room to counter it. ${ }^{30}$

Another point about orienting is: Piawang merusak timboThe point is not to let the leaders or rulers themselves intentionally damage the children of the country they lead. In the colonial period, leaders or rulers of the country tended to destroy the people they ruled. Country children who should be educated, find jobs, protected from poverty, on the other hand, deliberately destroy the foundations of their lives in various ways so that they are easy to control and easy to use. According to the elders, the above expression was based on the wisdom of the former Dutch colonialists in dealing with the children of the country they controlled. The Dutch in the past often used dignitaries or rulers who were appointed from among the children of their own country as pawns to deal with rebellious country children. However, this expression can happen in today's life if there are rulers who deliberately damage the life of the country. Rulers who behave inappropriately, gamblers, interest money, corruption, and so on cannot be used as role models and cannot be used as intermediaries or mediators in disputes to obtain consensus or make choices. ${ }^{31}$

The Qur'an explains that unity is the best way, divorce is destroyer. So the government should be the mediator of every problem that exists in the government. Allah SWT says in QS. Ali-Imran verse 103:

${ }^{29}$ Q.S. Al-Imran/3:159.

30 Thabran Kahar, Ungkapan Tradisional Sebagai..., p.248.

31 Ibid..., p. 252. 
IJIERM: Vol. 3 No. 1 January - March 2021

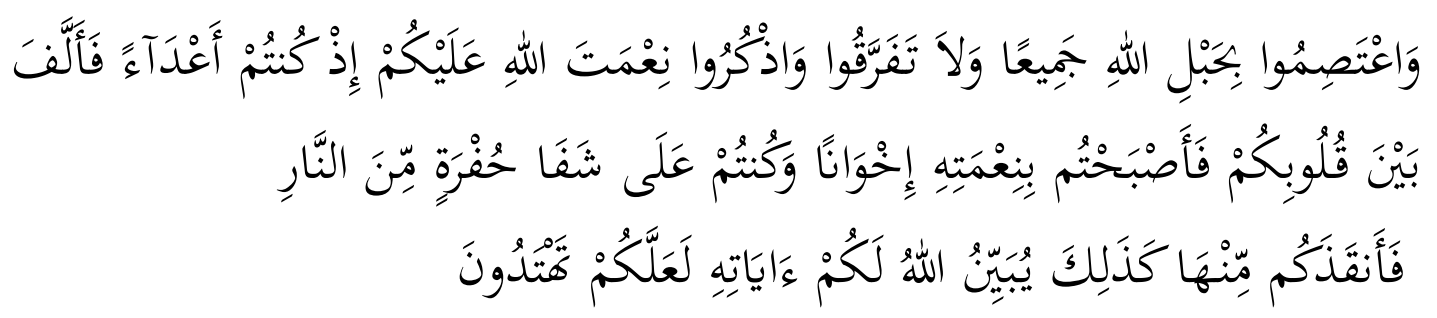

Meaning: "And all of you hold on to the rope (religion) of Allah, and do not be divided, and remember Allah's favor on you when you were enemies (the time of Jahiliyah), so Allah united your hearts, then you became because of Allah's favor those brothers; and you were on the edge of the abyss of hell, then Allah saved you from it. Thus Allah explains His verses to you, that you may be guided." 32

\section{f. Fair}

The principle of justice is an important thing to emphasize in the social life system of the community, as well as in local traditions, it does not mean that this noble value is ignored. In the Jambi Malay traditional seloko it is said: It's like breaking a botung when it's stepped on and a gi being lifted up high. The point is an act of injustice, found in the midst of life. This situation is opposed by previous ancestors to future generations. The leader at one time he protects a company on the other hand he ignores the company of a certain person. This expression can also be addressed to a father who discriminates in the education of his children, for example, boys are allowed to continue their education to college, while daughters are limited to junior high school and then quickly find a mate. Indeed, this expression contains many facets of purpose. ${ }^{33}$

Seloko justice is one of the criteria for leaders in Jambi Malay customsRajo adil, rajo disembag, rajo zalim, rajo disanggah; kalo bulat dapat digulingkan, pipih dapat diterbangkan, putih berkeadaan, merah dapat ditengok, panjang dapat diukur, berat dapat ditimbang; ke darat samo kering, ke air samo basah. ${ }^{34}$ This becomes a benchmark in choosing leaders and becomes a criterion that is tested under customary law, so that ethical leadership by upholding justice can become an exemplary figure.

Another lesson about justice is:. Meliat contoh pado nan sudah, meliat tuah pado nan monang. The point is to refer to past events as learning, many examples that must be considered in making decisions. The wrong example is not difficult to

32 Q.S. Ali Imran/3:103.

33 Thabran Kahar, Ungkapan Tradisional Sebagai..., p.260

${ }^{34}$ M. Ied Al-Munir dan Muslim H. Ja'far, 'Etika Kepemimpinan Dalam Seloko Adat Melayu Jambi', Kontekstualita, 28.2 (2013), 127-40. 
IJIERM: Vol. 3 No. 1 January - March 2021

distinguish from the right one, because we have experienced several incidents. Seeing the luck of a chicken is also done by people after the chicken wins in the competition. The right thing must be taken to be used as a guide in making decisions. Of course experience plays an important role in considering the right and wrong of an issue. The arguments can be arranged in argumentation in an effort to defeat and reveal wrong conclusions from parties who like to distort reality. ${ }^{35}$

This principle is closely related to the Word of Allah SWT that humans in God's view are the same, if they do good with their professionalism, they will be rewarded as long as they believe in Him. The word of God in QS. An-Nisa' verse 58, Thaha verse 112, QS. An-Nahl verse 97 and an-Nahl verse 90:

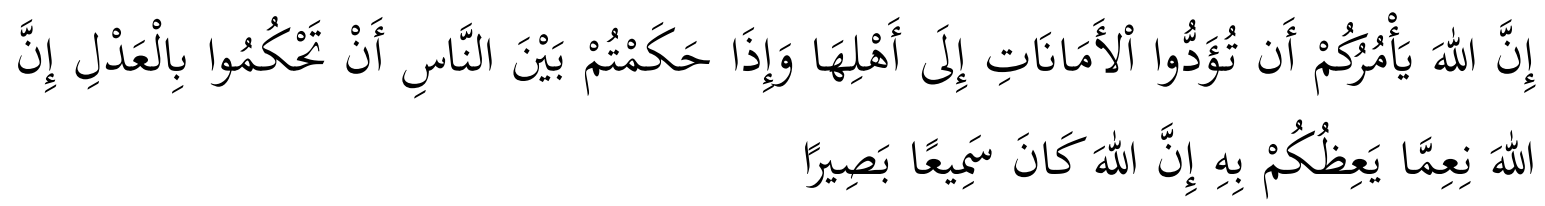

Meaning: "Indeed Allah commands you to convey the mandate to those who are entitled to receive it, and (orders you) when determining the law between humans so that you judge with justice. Verily, Allah has taught you the best. Verily Allah is All-Hearing, AllSeeing." 36

\section{g. Effective and efficient}

Effectiveness and efficiency in the government system can be seriously considered by its leaders. In the Jambi Malay traditional seloko it is said: : Dikit menjadi pembasuh banyak menjadi musuh. The point is that demanding something excessively is not good, just as excessive amounts of water can cause flooding, which can wreak havoc. Only in a certain amount of water can be a human friend, especially if needed just for washing just a little bit. Circumstances like this symbolize the needs that humans need have been determined. If the need exceeds its size, it can cause bad things, for example, the desire to accumulate wealth can disturb one's peace of mind. Wealth can enslave people. Managing excessive wealth is no different than controlling a raging flood regardless of what lies ahead. The great flood will hit anything that stands in its way. Actually, people may accumulate wealth, but do not be based on the guidance of lust that is never satisfied. So it is natural for everyone not to demand something excessively. ${ }^{37}$

Likewise with the statement of the Qur'an that working effectively and efficiently is working with professionals who produce something that is expected,

35 Thabran Kahar, Ungkapan Tradisional Sebagai..., p.147.

${ }^{36}$ Q.S. An Nisa/4:58.

37 Thabran Kahar, Ungkapan Tradisional Sebagai..., p.200 
IJIERM: Vol. 3 No. 1 January - March 2021

then the Qur'an reminds you that if you have finished a productive job, keep looking for better productivity, as follows: in QS. Ash-Syarh verses 7 and 8:

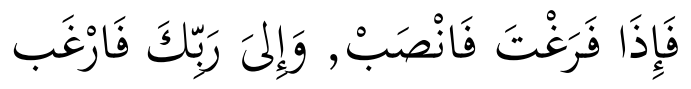

Meaning: "So when you have finished (from a business), do it seriously (business) another, and only to your Lord should you hope."38

\section{h. Accountability}

Being responsible in every period of life can be tested in various ways, so that accountability is strong enough to serve as a principle in building a system or government policy. In the Jambi Malay traditional seloko it is said: Gangan eel belango is long, don't want to slide aek on the board. The point is don't prolong a problem, like water spilled on a board will quickly flow to and fro which will eventually wet all surfaces. This situation is expressed in the form of an expression that likens a problem that is not quickly resolved so that it develops into a bigger and more serious one. The problem that is allowed to grow is of course feared that it will have bad consequences. Therefore, before a problem becomes big, it must be resolved as soon as possible. This phrase is very well practiced by everyone. ${ }^{39}$

Other seloko related to Accountability are: Tie to make a promise semayo. The point is that this expression contains an advice that everyone who makes an agreement should be locked with a sign so that the agreement is not easily changed. Apparently there are clues to the habits of the ancients or some people who have promised but break their promise, so that there is no accountability and brings loss to one party. ${ }^{40}$

The Qur'an explains that conveying and carrying out the mandate is obligatory, even in law enforcement or all aspects of social life, so this trust in the principles of good governance is known as accountability, as the following word in QS. An-Nisa' verse 58:

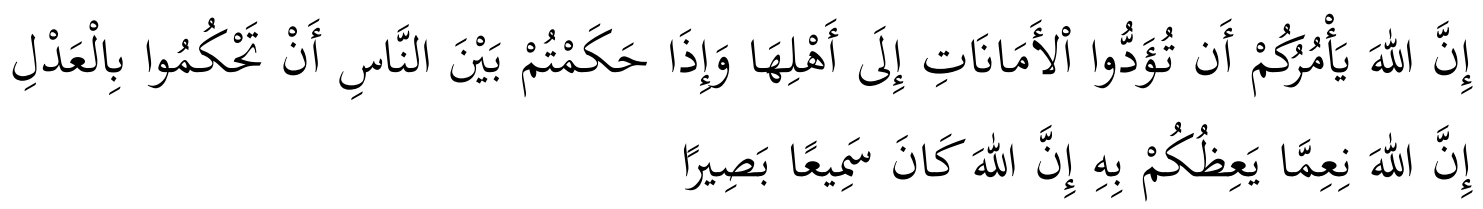

38 Departemen Agama RI, Al-Qur'an Dan Terjemahannya (Tangerang: PT. Indah Kiat Pulp dan Papek Tbk, 2007). p. 280.

39 Thabran Kahar, Ungkapan Tradisional Sebagai..., p.200

40 Ibid..., p.269. 
IJIERM: Vol. 3 No. 1 January - March 2021

Meaning: "Indeed Allah commands you to convey the mandate to those who are entitled to receive it, and (orders you) when determining the law between humans so that you judge with justice. Verily, Allah has taught you the best. Verily Allah is All-Hearing, AllSeeing." 41

\section{i. Strategic vision}

Good governance is proposed and programmed as an effort to form a better human life system. In the Jambi Malay traditional seloko it is said: Di mano titik di sano ditampung, di mano patah di sano disisip, di mano terbit di sano dituai.. The point is not to worry too much about the problems that will occur because humans throughout their lives are always filled with problems, so don't be too afraid to face them. People who are always afraid of various problems will experience various obstacles so that it is feared that they will not be able to overcome this life well. At any time a problem can occur, then that's when we are ready to overcome it. Problems are not to be avoided but overcome. Of course people who can do that are people who have prepared themselves thoroughly. ${ }^{42}$

Another Seloko reads: Mudik setanjung ilir serantau, The point is that a job should be completed step by step because the success of a task or job lies in the program that is prepared either by individuals or together. In the program there are stages that must be carried out. Expertise determines what should be prioritized and left behind. Wisdom like this not only exists today but has existed among ancient societies. Apparently, ancient people believed that if they wanted to succeed in doing something, they had to do it step by step according to the plan that had been prepared. In the life of a farmer, for example, there is a time of cutting and slashing, there is a time of burning and slashing, there is a time of climbing or slashing, there is a time of weeding, keeping birds out, and there is a time of harvesting. The phasing has to do with their ability to study the properties of nature. Nature they make a teacher. ${ }^{43}$

Likewise, the Qur'an informs Muslims and leaders to have a strategic vision to realize good governance by looking forward to the principles of the future with a reliable strategy, as the Word of Allah SWT in QS. Al-Hashr verse 18:

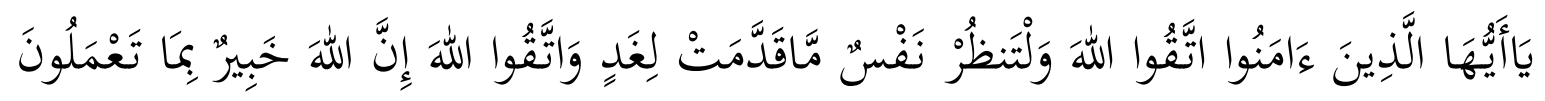

${ }^{41}$ Q.S. An-Nisa/4:58.

${ }^{42}$ Thabran Kahar, Ungkapan Tradisional Sebagai..., p.260

${ }^{43}$ Ibid..., 190 
IJIERM: Vol. 3 No. 1 January - March 2021

Meaning: "O you who believe, fear Allah and let everyone pay attention to what he has done for tomorrow (hereafter), and fear Allah, verily Allah is Knowing of what you do."44

The discussion above shows that Jambi Malay traditional seloko has an Islamic spirit with various arguments mentioned in each principle of good governance in the system of government or life. Various searches related to these relations and principles can also be examined in the content of the Qur'an, such as; good government should not commit falsehood in every bureaucracy (Q.S. AnNisā ': 29); cooperate and kinship (Q.S. surah al-Maidah: 2); democracy and Deliberation (Q.S. Ash-Shura: 38); justice and equality (Q.S. An-Nahl: 90; Al-Hasyr: 7); life and balance (Q.S. Al-Qashash: 77); legal awareness (Q.S. An-Nisā': 59 and 65); optimism (Q.S. Ali Imran: 159); and security and tranquility (Q.S. Al-Baqarah: 126).

Seloko adat is strengthened by the argument of the Qur'an, making the Jambi Malay community stronger to pass on to future generations. In the system of social life and government. Because the mindset held by traditional leaders, religious leaders and parents in social life is the value of character. ${ }^{45}$ Even sometimes the values contained in Jambi Malay customs support each other and strengthen their role in building good governance. Like the Jambi city government, through the program "rise empowered" and "musrembang" activities, 46 they try to instill the values of gotong royong, independence, and deliberation. Gotong royong has become a social system and a tradition that is maintained and well-maintained. ${ }^{47}$

\section{CONCLUSION}

The principle of good governance that develops in the customary perspective of the government system is very relevant to the concept of customary governance which is constructed in the seloko adat Malay Jambi. Good governance eventually accompanies the life of the Jambi Malay community and continues to be maintained and even inherited by the indigenous peoples as a manifestation of the

${ }^{44}$ Q.S. Al-Hasyr/59:18.

45 Made Purna dan Sri Minstosih, Nilai Budi Pekerti Dalam Pantun Melayu (Jakarta: Departemen Pendidikan dan Kebudayaan, 1993).

46 Nopriyandri dan Saidina Usman, 'Penerapan Nilai-Nilai Adat Melayu Adat Jambi Dalam Mewujudkan Good Governance Di Lingkungan Pemerintah Kota Jambi', Jurnal Sains Sosio Humaniora, 2.2 (2018), p. 113-26.

47 Jauhar Mubarok Evawarni, Nuraini, Tradisi Kumpul Sanak Di Sekernan, Muaro Jambi, I (Riau: Balai Pelestarian Nilai Budaya Kepulauan Riau, 2017). 
IJIERM: Vol. 3 No. 1 January - March 2021

integration of the principles of good governance in Jambi Malay customs which are integrated in seloko adat and petatath petitih. The theory of good governance in the Jambi Malay traditional language is thick with Islamic nuances, indirectly has included the message of the Qur'an and is automatically in line with Islamic teachings through the arguments obtained from the Qur'an. 
IJIERM: Vol. 3 No. 1 January - March 2021

\section{BIBLIOGRAFI}

A. Wahab Madjid, Garis-Garis Besar Pedoman Adat Bagi Pemangku Adat Dalam Kotamadya Dati II Jambi (Jambi: lembaga Adat Tingkat II dan PemerintahanKotamadya Dati II Jambi, 1995)

Agus Dwiyanto, Reformasi Birokrasi Publik Di Indonesia (Yogyakarta: Gadjah Mada University Press, 2006)

Evawarni, Nuraini, Jauhar Mubarok, Tradisi Kumpul Sanak Di Sekernan, Muaro Jambi, I (Riau: Balai Pelestarian Nilai Budaya Kepulauan Riau, 2017)

Haris, Oheo K., 'Good Governance (Tata Kelola Pemerintahan Yang Baik) Dalam Pemberian Izin Oleh Pemerintah Daerah Di Bidang Pertambangan', Yurdika, 30.1 (2015)

Ja'far, M. Ied Al-Munir dan Muslim H., 'Etika Kepemimpinan Dalam Seloko Adat Melayu Jambi', Kontekstualita, 28.2 (2013)

Jambi, Lembaga Adat Provinsi, Pokok-Pokok Adat Pucuk Jambi Sembilan Lurah,Jilid II (Jambi, 2001)

Lembaga Adat Provinsi Jambi, Pokok-Pokok Adat Pucuk Jambi Sembilan Lurah Jilid I (Jambi, 2001)

M.D, Sagimun, Adat Istiadat Daerah Jambi (Jakarta: Departemen Pendidikan dan Kebudayaan, 1978)

Made Purna dan Sri Minstosih, Nilai Budi Pekerti Dalam Pantun Melayu (Jakarta: Departemen Pendidikan dan Kebudayaan, 1993)

Nopriyandri dan Saidina Usman, 'Penerapan Nilai-Nilai Adat Melayu Adat Jambi Dalam Mewujudkan Good Governance Di Lingkungan Pemerintah Kota Jambi', Jurnal Sains Sosio Humaniora, 2.2 (2018)

RI, Departemen Agama, Al-Qur'an Dan Terjemahannya (Tangerang: PT. Indah Kiat Pulp dan Papek Tbk, 2007)

Sedarmayanti, Good Governance; Kepemerintahan Yang Baik (Bandung: Penerbit Mandar Maju, 2004)

Syarkani, Re-Spiritualizing Governance (Yogyakarta: Pustaka Pelajar, 2010) 
IJIERM: Vol. 3 No. 1 January - March 2021

Thabran Kahar, Ungkapan Tradisional Sebagai Sumber Informasi Kebudayaan Daerah Jambi (Jambi: Departemen Pendidikan dan Kebudayaan, 1987)

Wybo P. Here, ed., From Governance to Governance, the Growing Impact of Non-State Actors on the International Dan European Legal System (Netherlands: TMC ASSER PRESS, 2003) 